\title{
Introduction
}

In a call for papers for the 'Women in German Annual Conference 2007', the organizers introduce the notion of Europe as 'contested terrain':

The transatlantic tensions in the run-up to the Iraq invasion produced, for a while, the heady possibilities of imagining Europe as counterweight to American-style globalization. And while some believe that that utopian window has closed, we think it is still necessary to explore Europe as contested terrain - caught between colonial, imperialist, fascist, and totalitarian histories and their legacies (Pim Fortuyn's Europe, as Arjun Appadurai has called it), and the enlightened, postEurocentric, antifascist Europe that is committed to learning its lessons from the past (Bassam Tibi's Europe). ${ }^{1}$

In this book, I, too, wish to explore Europe as contested terrain. For me, as for the organizers of the 'Women in German Annual Conference 2007', the point of departure is transatlantic tensions. Transatlantic feelings are not as warm as they used to be, and if Timothy Garton Ash is correct in his assessment that the old Atlantic-centered West only has about twenty more years in which to play at least some part in setting the agenda of world politics and in seeking solutions to global problems such as global warming, the widening gap between rich and poor countries, and terrorism, then it really is 'stupid for Europeans and Americans to waste any more time squabbling with each other'.2

The run-up to the Iraq invasion may indeed have made Americans on the Left view Europe as a counterweight to American-style globalization for a while. Chances are, though, that these Americans would soon have gone back to a much less positive view of Europe - one that would tend to associate Europe with genocide, colonialism and aggression (Pim Fontuyn's Europe). Let me mention one small personal experience as an illustration: on the evening in July 2006 when it became clear that the last four teams to remain

1 'Contesting Europe: Feminist Critiques and Globalization' - call for papers for the 'Women in German Annual Conference (WiG)', to be held at Snowbird, Utah, 18-21 October 2007. This call for papers used to be available at www. womeningerman.org (last visited on 3 March 2007).

2 Timothy Garton Ash, Free World: America, Europe, and the Surprising Future of the West (New York: Vintage Books, 2004), 176. 
in the 2006 Football World Cup - the four semi-finalists, that is - were all European teams, an American friend informed me that she was very disappointed about this turn of events, and that she could never ever support a European team. To my amazed question why this was the case, she rather emphatically answered: 'Because Europe colonized South America'.

This was by no means the first time that I had encountered such an antiEuropean attitude on the part of otherwise well-meaning and progressive Americans. Within American Studies circles it has led, for example, to a refusal by some to deal with the European past of what was to become the United States. Instead, it is the Asian-American, the African-American and other non-European pasts that receive scholarly treatment. Europe, it would seem, has simply become politically incorrect.

On the European side, unfortunately, things do not look much better. I regularly teach courses on human rights, both to students at my own university and to students from all over Europe in the European Master's Degree in Human Rights and Democratisation in Venice. ${ }^{3}$ To these students, who are always very dedicated to the promotion of human rights worldwide, I speak of American and European perceptions of human rights. Most often, these young Europeans have a hard time accepting that there may be reasons why the US is acting as it is. It is quite clear that the US is the absolute enemy for them. They point - not unreasonably - to the way in which the US refuses to ratify international human rights treaties and to support the International Criminal Court, as well as to the role played by various US administrations in fostering hostilities around the world. What always surprises me, however, is the lack of knowledge, on their part, of the strong American rights tradition and belief in the rule of law.

I always wonder during such encounters what can be done to ease transatlantic intellectual tensions. On the American side, left-wing anti-European sentiments have played into the hands of the George W. Bush administration and the contempt shown by its neo-conservative supporters toward what former Secretary of Defense Donald Rumsfeld famously called, a few years ago, 'Old Europe'. And on the European side, anti-American feelings have at times been so strong that they have exerted a powerful influence on European politics. What motivates me to write about this issue is the feeling or hope that it may help to remind people on both sides of the Atlantic of the intellectual and cultural heritage that unites us. A useful first step toward initiating dialogue with one's 'adversary' is to understand where this adversary comes from. Many scholars and writers have focused on that which separates us. This is important - but it is no less important to stress whatever common ground there may still be.

3 For more information about the programme, please see www.emahumanrights. org. 
Among the elements that make up our shared intellectual and cultural heritage, one of the most important is our rights tradition. Those same Americans who denounce Europeans as colonizers and aggressors only will be the first to use their courts to fight for equality and for the rights of minorities. And those same Europeans who scorn the US for failing to commit to international law and human rights are well on their way not only to supplanting their parliamentary democracies with constitutional democracies, Americanstyle, but also to using solutions to current European problems with multiethnicity that look oddly familiar from an American context. Rights, in other words - or what Mary Ann Glendon once called 'rights talk' ${ }^{4}$ - are central to who we are and to how we intend to solve problems on both sides of the Atlantic. They are a European 'invention', going back to Enlightenment philosophers such as Locke, Rousseau and Montesquieu, but it was in the US that they first came to play a major role in political, social and cultural life.

The main argument here will be that Europeans have attempted for some time to develop their own version of rights talk: a human rights talk. European intellectuals as well as European Union politicians and policy professionals are talking about the need to construct 'European narratives'. What they have in mind are narratives that will emphasize a political, but also a cultural, vision for a multi-ethnic and more cosmopolitan Europe. These narratives evolve around human rights, partly because their authors hope that they may function as a kind of cultural glue in an increasingly multi-ethnic Europe, and partly because they are intimately connected with that part of Enlightenment thinking that sought to promote democracy and the rule of law. In addition, modern Europe is 'self-reflexive', argues German sociologist Ulrich Beck; it is built on a conscious wish to learn from the terrible mistakes of the past, and this also makes human rights central.

Human rights, that is, is developing into a discourse of atonement as well as of hope for these Europeans. It is a discourse that speaks to Bassam Tibi's, and not Pim Fontuyn's, Europe - to the enlightened, post-Eurocentric, antifascist Europe that is committed to learning its lessons from the past. And it is a discourse which has the potential to become a shared, transatlantic discourse.

\section{THE NINE CHAPTERS}

This book is divided into nine chapters. Chapter 1, 'A soul for Europe? On European culture and narratives of human rights', opens with German film

4 See Mary Ann Glendon, Rights Talk: The Impoverishment of Political Discourse (New York: Free Press, 1991). 
maker Wim Wenders's argument, presented at the 2006 'A Soul for Europe' conference in Berlin, that Europe does indeed have a soul - a soul that is to be found not so much in its politics or in its economy, but in its culture. In order that Europeans may be 'won' over, may see the emotional potential of 'Europe', it is important that European artists commit themselves to creating European literature, art and films. Wenders's emphasis on culture is echoed by European Union (EU) politicians and policy makers who have lately turned to 'culture' as a possible instrument for popularizing Europe.

One of the most important current cultural discourses in the European context is arguably the discourse of human rights. Arguments are being circulated in favour of seeing human rights as a defining characteristic of European culture and identity. European narratives of human rights are presented by both European intellectuals such as Ulrich Beck and Edgar Grande and EU politicians and policy makers who focus on human rights as a kind of cultural glue. The Europe we meet in these narratives is a chastened and realistic Europe that has admitted to and worked through the many horrible mistakes in its past - a self-reflexive Europe. In the last two chapters of the book, we shall get (back) to those creative narratives of human rights that Wenders would like European artists to construct. The narratives presented in Chapter 1 are of a more intellectual and/or policy oriented kind. But this does not mean that they are any less preoccupied with cultural matters.

What it does mean, though, is that intellectuals and policy makers succeed in avoiding some of the problems that invariably present themselves to anyone attempting to deal in a more direct way with the concept of 'European culture'. We take a closer look at these problems in Chapter 2 which is entitled 'The problem(s) with European culture'. Both 'Europe' and 'culture' are entities that have been problematized over the past many years. What does 'Europe' mean - is it a geographical entity or a state of mind? And the concept of 'culture' - does it encompass the fine arts only, or do we think of an entire way of life when we refer to 'culture'? When the two concepts are put side by side, moreover, and we start to talk about 'European culture', even more problems turn up. This makes it hard to discuss Europe and its future without touching upon politically incorrect or sensitive ground.

As several of the intellectuals whose work we look at in Chapter 2 argue, though, this is necessary. In order to get to a fruitful discussion of the current and possible future state of transatlantic relations, we must get at least some idea of what 'Europe' and 'European culture' encompass. And interestingly enough, any discussion of these issues has as its subtext the United States; the differences or similarities of Europe to the US and the relationship, historical and present, between these two parts of the world are invariably touched upon by Europeans today who try to figure out what 'Europe' and 'European culture' might mean. For some, who may not formerly have believed in 
'Project Europe', it is the need NOT to become like the US and to fight the enormous political and cultural power of the world's only remaining super power that today defines 'Europe'.

It should be clarified at this point that throughout the book, the transatlantic dialogues that interest me are both the dialogues conducted on the part of European and American intellectuals, policy makers and artists, and also the dialogues conducted between the EU and the US. This means that I do not get into the differences that exist between mainland Europe and Great Britain - for example in terms of the civil-law systems of the mainland European countries versus the British common-law system - or between the various traditions in mainland Europe itself. I mostly talk about Europe as one entity, and my focus is on intellectual responses that present themselves as 'European' or see themselves as coming out of a European tradition as well as on the official reaction of the EU toward the various issues dealt with in this book. Doing research for the book, I have been amazed at the many reports and books that are published by both the EU and the Council of Europe and that cover a lot of different issues - and I have been positively surprised at the quality, both of the reports and books written for a wider audience and of those written for a more scholarly audience.

I confess to finding the experiment in supranational governance that is the EU not only intriguing, but also promising. And I think that if transatlantic dialogues are going to improve, Europeans will have to work through the EU to be taken seriously by the US. Though bearing at times witness of window dressing, official reactions between the US and the EU are relevant - if only to give us a hint as to the direction in which things seem currently to be moving. 'If the union did not exist, it would not now be created', writes Professor Anand Menon in his conclusion to Europe: The State of the Union (2008). I am afraid that Menon is right, and what a shame this would be:

War, material devastation, fear, and the unusual status and mindset of the continent's most powerful country combined in the 1940s to create a unique historical moment in which sovereign nation states consented to relinquish a part of their autonomy in order to accomplish something together. Yet it does exist, and the member states would be all the poorer - both literally and metaphorically - without their unlovable Union. ${ }^{5}$

Chapter 3 concerns 'Transatlantic dialogues, past and present'. In the first part of the chapter, we will look at transatlantic perceptions - at the way in which 'Europe' has always had a special place in the American imagination,

5 Anand Menon, Europe: The State of the Union (London: Atlantic Books, 2008), 252. 
just as 'America' has been an object of the European imagination from the very beginning. An understanding of this cultural dynamic, which has given rise over the years to much friendly curiosity but also to many prejudices, is crucial to an assessment of today's European anti-Americanism and American anti-Europeanism as well as of the consequences these have for transatlantic policy. What have developed into political problems on the world scene today, it will be argued, originate to a large extent as cultural problems.

We will then move on, in the second part of the chapter, to look at some of the official EU dialogues with the United States. Interestingly enough, these seem to be in somewhat better shape than the transatlantic perceptions would make us think. At the official level, the EU has pronounced its willingness to pursue, together with the US, issues of importance to people on both sides of the Atlantic (as these are revealed in various surveys), such as the need to do something about current environmental problems and to combat international terrorism. When we 'deduct' from the official rhetoric the inevitable element of window dressing, mentioned above, the fact remains that dialogues are taking place on issues on which the EU and the US do not agree - environmental problems and the fight against international terrorism being two of the very best examples - but on which their respective populations ironically enough want them to find a common solution. This is, in my opinion, a hopeful sign.

Among the official EU-US dialogues are twice-yearly meetings dedicated to human rights. These meetings are mostly focused on issues related to the fight against terror, though. They do not touch on broader human rights issues. From time to time, there have been informal attempts at starting a broader dialogue, but apart from such attempts and from the meetings focusing on the fight against terror, the closest we get to transatlantic dialogues on human rights are the dialogues the EU and the US are having with third world countries. These official EU-US dialogues will be the topic of Chapter 4, 'Institutionalized European human rights'.

We will furthermore look, in Chapter 4, at the two European courts: the European Court of Justice (ECJ) and the European Court of Human Rights (ECtHR). As some see it, the two European courts roughly divide the functions of the US Supreme Court between them: the ECJ resolves questions that concern the regulation and the division of power between EU Member States and between the EU and its Member States, whereas the ECtHR deals with questions concerning the fundamental rights of citizens of the member states of the Council of Europe, as these are laid down in the European Convention on Human Rights and the protocols supplementing it. By most criteria, these two courts have been very successful. Some critics have reacted to this very success by claiming that it has led to a prevalence of law over politics, which in turn has led to an impoverishment of the political sphere. In order to solve 
human rights violations in Europe, these critics furthermore argue, it will not do to focus exclusively on redress by the courts. The discussion of law versus politics is one we shall return to repeatedly in other chapters.

The interesting parallels between the American and the European high courts and their way of interpreting fundamental rights notwithstanding, a number of transatlantic tensions come together or are expressed in the area of human rights. In Chapters 5 and 6, on 'Divergent transatlantic views on human rights: economic, social and cultural rights' and 'Divergent transatlantic views on human rights: the role of international law', respectively, we shall analyse two human rights areas or issues on which there is disagreement. The first of these is the core of human rights, the kinds of (human) rights emphasized, and the second is the attitude toward international law and international human rights regimes. Whereas Americans tend to think that the core of human rights consists of first-generation rights only (the civil and political rights), many Europeans tend also to believe in second-generation rights as a foundation for their welfare states. And when it comes to the international situation, Europeans are, again generally speaking, more willing to promote international law and human rights institutions than are Americans - even at the 'cost' of subsuming national law and national concerns under those of supranational law.

Chapter 7 deals with 'Transatlantic dialogues on copyright: cultural rights and access to knowledge'. Copyright, it will be argued, will increasingly set the parameters for creativity by allowing or prohibiting the reproduction of vital cultural texts - texts that help define the cultural milieu in which we live. Holders of copyright are in some senses able to exert monopolies over public meaning, and the more people will engage actively with commodified cultural forms - the more our culture becomes one of consumption - the more power these holders will have. Issues of copyright have everything to do with the sort of cultural politics going on, not only within Europe, but also across the Atlantic Ocean, that have been the focus of attention throughout.

We shall look, first, at cultural rights as these relate to the formation of identity - local, European and global. We shall then zoom in on the movement for access to knowledge. The fight for access to knowledge has a lot to do with cultural pride. Ostensibly about who owns the right to knowledge - and thus about issues having to do with copyright protection - the underlying issue is cultural copyright: gaining respect and recognition for oneself and/or for one's culture. The discussion of access to knowledge will be followed by a discussion of other copyright-related issues. There has been a tendency in recent times for human rights discourses to trespass into areas in which they were previously unknown. Copyright (and intellectual property as a whole) is a prime example of such an area - a reflection, in our current knowledge societies or economies, of the importance of cultural issues, especially as these 
relate to identity and cultural pride. In the copyright area, no less than in other areas in which 'culture' has become an 'issue', there are certain interesting transatlantic angles that reflect back on several of the transatlantic themes we have looked at in previous chapters.

In Chapters 8 and 9 we shall stay within the realm of culture. As its title, "Transatlantic dialogues on "law and literature": from "law and literature" to "law and humanities", , implies, Chapter 8 argues that the time has come for law and literature scholars to broaden their field somewhat. It is not only in literary works of fiction that law and order are constitutive of dramatic action; non-literary works are also full of fights between good and evil and of themes such as justice, revenge and crime and punishment. Negotiations on societal values are taking place in many different public spaces. And precisely because so many of these important discussions are carried out in a legalistic, rightstalk vernacular, scholars studying law and humanities may be able to help both the general public and their fellow academics understand what the underlying and really significant issues are.

Chapter 9, 'Transatlantic dialogues on film: the case of Lars von Trier', presents Lars von Trier's so-called 'America trilogy' as 'evidence' that films are a worthy study for law and humanities scholars. It will be argued that Trier is being anti-American in an all- or semi-American way and that his work touches upon many of the 'big' themes that are of relevance in a law and humanities context. We shall take a brief look at some of the early films in order then to concentrate on three of Trier's later films - Dancer in the Dark, Dogville and Manderlay. These are set in the United States and feature, at least to a certain extent, American themes and concepts. It is Trier's way, in these later movies, of being critical of the US while simultaneously making much use of American phenomena and themes that is of interest. He is one of those European film makers and artists currently constructing that soul for Europe of which Wim Wenders speaks with such warmth. With his love-hate relationship with the US Trier joins the ranks of European critics and commentators such as Zygmunt Bauman and Ulrich Beck, just to mention a couple whose works we will discuss throughout the book, for whom 'America' is much more than just a nation or a place.

\section{WORKING ON LAW AND HUMANITIES AS A CULTURAL HISTORIAN}

I see myself as a law-and-humanities scholar and the work that I do as belonging within the discipline or area of law and humanities. My approach is that of the cultural historian or the historian of ideas rather than that of the literary scholar or the lawyer. Indeed, this is one reason why I argue, in this book, that 
law and literature ought to be broadened into law and humanities. Discussing transatlantic dialogues on human rights from a cultural-historical point of view is, in my opinion, just as much 'doing' law and humanities as is undertaking a legal-rhetorical interpretation of a play by William Shakespeare or a legal decision.

Doing interdisciplinary work and bringing together various fields of inquiry, as Stanley Fish once famously remarked, 'is so very hard to do'. ${ }^{6}$ Some attempts are obviously more successful than others. Not being a legal expert myself, I have tried, where I thought it appropriate and needed, to stay close to the writings of scholars who are. By quoting people in the know about legal areas that I do not myself master and by asking colleagues to read through various chapters to verify the factual assertions that are made, I hope to have avoided the worst mistakes. There may still be some left, of course, and for these I apologize in advance.

My way of 'doing' law and humanities means, furthermore, that I may not always be as empirical as 'real' historians might wish me to be. Where are concrete analyses of events in the Middle East and other places where the US and the EU see issues related to human rights differently and call for different solutions, such historians may ask? To this I can only answer that, as a cultural historian, I am interested in laying bare the underlying cultural issues - those issues that shape people's lives, make them think and act as they do. It is the 'why did they do this?' behind that 'what did they do?' that is my main concern. And when interpretations of concrete events have been called for that I have not felt competent to make myself, I have attempted to find expert historical writing to guide me.

Because I believe in 'Project Europe' and because I think that an improvement of transatlantic relations will have to go through the EU, it makes me frustrated to hear Americans say incorrect things about Europe, and to hear Europeans say prejudiced and stupid things about America. All that I can do perhaps to correct such wrong and dangerous impressions as an academic is to write a book which attempts to state matters fairly and to see things from both sides. If only people on either side of the Atlantic would make the effort to understand why these 'stupid Americans' or these 'stupid Europeans' react as they do - then the transatlantic relationship would be in much better shape.

6 Stanley Fish, There's No Such Thing as Free Speech: And It's a Good Thing Too (New York: Oxford University Press, 1994), 231. 